\title{
Genetics of resistance to mastitis in dairy cattle
}

\author{
Rachel RUPP ${ }^{a *}$, Didier BOICHARD ${ }^{\mathrm{b}}$ \\ ${ }^{a}$ INRA, Station d'Amélioration Génétique des Animaux, BP 27, 31326 Castanet-Tolosan, France \\ b INRA, Station de Génétique Quantitative et Appliquée, 78352 Jouy-en-Josas, France
}

(Received 31 January 2003, accepted 28 April 2003)

\begin{abstract}
Genetic variability of mastitis resistance is well established in dairy cattle. Many studies focused on polygenic variation of the trait, by estimating heritabilities and genetic correlation among phenotypic traits related to mastitis such as somatic cell counts and clinical cases. The role of Major Histocompatibility Complex in the susceptibility or resistance to intrammamary infection is also well documented. Finally, development from molecular genome mapping led to accumulating information of quantitative trait loci (QTL) related to mastitis resistance and better understanding of the genetic determinism of the trait. From economic and genetic analyses, and according to welfare and food safety considerations and to breeders and consumer's concern, there is more and more evidence that mastitis should be included in breeding objective of dairy cattle breeds. Many countries have implemented selection for mastitis resistance based on linear decrease of somatic cell counts. Given biological questioning, potential unfavourable consequences for very low cell counts cows are regularly investigated. Improvement of selection accuracy for mastitis resistance is ongoing and includes: advances in modelling, optimal combination of mastitis related traits and associated predictors, such as udder morphology, definition of global breeding objective including production and functional traits, and inclusion of molecular information that is now available from QTL experiments.
\end{abstract}

mastitis / somatic cell count / genetic parameter / QTL / breeding program / dairy cattle

Table of contents

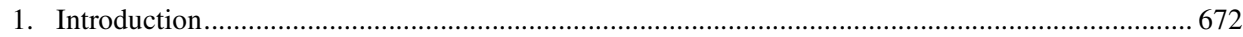

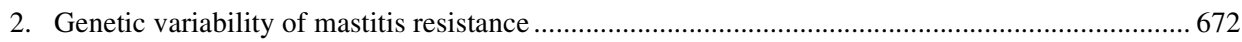

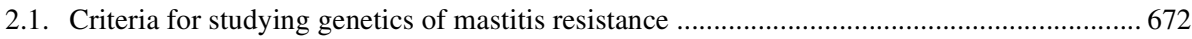

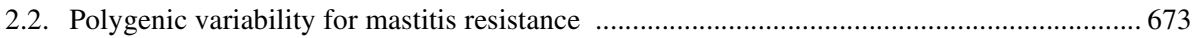

2.2.1. Genetic parameters for bacteriological count, clinical mastitis, and SCC ................ 674

2.2.2. Genetic variability of immune mechanisms underlying mastitis resistance .............. 675

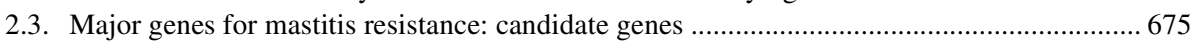

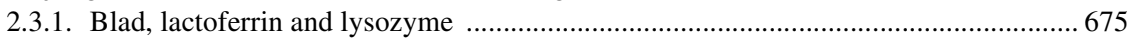

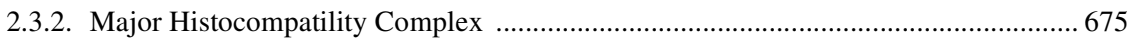

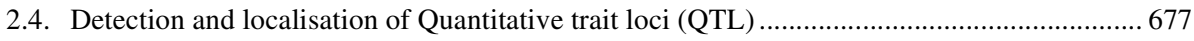

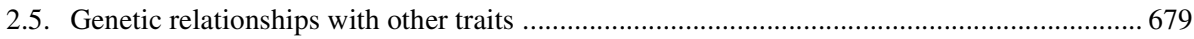

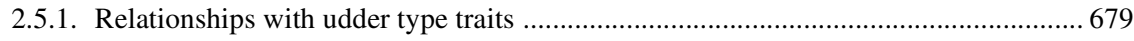

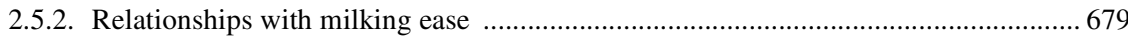

\footnotetext{
* Corresponding author: rupp@toulouse.inra.fr
} 
2.5.3. Relationships with milk production traits 680

2.5.4. Relationships with fertility and functional longevity ............................................680

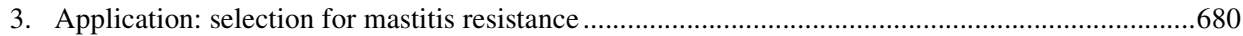

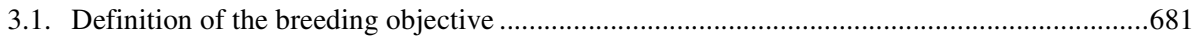

3.2. Selection criteria: clinical mastitis or somatic cell counts? ................................................681

3.3. Genetic evaluation and inclusion in breeding programs..............................................682

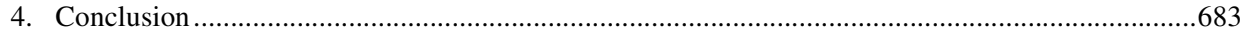

\section{INTRODUCTION}

Mastitis resistance is a complex trait, depending on a genetic component but also on physiological and environmental factors, including infection pressure. On the most global scale, resistance could be defined as the ability to avoid any infection or the quick recovery from an infection. But resistance could also be defined regarding particular pathogens, and/or particular defence mechanisms. Most genetic studies focused on milk somatic cell counts (SCC) and clinical mastitis as phenotypic measure to predict the bacterial status of udders $[27,51]$. Accumulating results show moderate and low heritability for SCC and clinical mastitis, respectively, and accumulating QTL experiments led to the localization of regions involved in the determinism of those traits. Genetic variability for mastitis resistance represents only a small proportion of the total variance but is not negligible and provides some interesting selection opportunity, and should be considered as an attractive complementary way to improve mastitis resistance in dairy cattle. Indeed, although sanitation is an efficient and primordial way to control mastitis, it remains a frequent and erratic disease with large economic consequences [41, 78]. Up to day, there is a lack of efficient vaccination, and research to enhance the cow's defense mechanism is ongoing [98]. Further, in many countries, frequency of clinical mastitis increased over time, at least in Holstein population. This trend resulted from the efficient selection based on productivity and from the genetic antagonism between milk production and mastitis resistance [90]. Accordingly, many years after the
Scandinavian countries, most breeding schemes were reoriented in the 90's to efficiently include mastitis resistance in the objective and stop any unfavourable trend.

This paper first reviews the state-of-theart on the genetic variability underlying mastitis resistance. Second, we describe how mastitis resistance is accounted for in dairy cattle selection, according to the conventional stepwise procedure: definition of the breeding objective, choice of selection criteria, estimation of breeding values, and inclusion in breeding programs.

\section{GENETIC VARIABILITY OF MASTITIS RESISTANCE}

\subsection{Criteria for studying genetics of mastitis resistance}

Phenotypic measures of mastitis resistance are usually classified into two groups: direct measures, corresponding to the diagnosis of infection (bacteriology, observation of clinical cases), and indirect measures, which consist in a prediction of the bacteriological status of the udder based on inflammatory parameters (somatic cell counts, conductibility, ...). The bacteriological analysis of milk is the most accurate direct criterion, because it provides precise and exhaustive information on infected quarters, pathogen involved. However, sensitivity is not one based on one culture (especially for Escherichia coli infected quarters). Therefore repeated measurements are needed, which can also give information on the time onset and the persistence of infection. For genetic purpose, it is rarely used because it 
is difficult and expensive to implement at large scale.

Conversely, clinical cases of mastitis are easy to record, either as occurrence, treatments, or culling, as done in Scandinavian countries for more than 20 years [27]. Nature of clinical mastitis data is therefore categorical and treated either as all or none (presence or absence) trait or repeated events over the lactation. In other countries, large clinical mastitis data are scarce but investigation for standardisation and generalized recording is ongoing. Interpretations of such data, however, present important limits: how to distinguish recurrence of same infection from new infections? How to appreciate completeness of detection, principally done by the farmer during milking? Moreover, clinical mastitis does not give any information about fully subclinical intrammamary infections.

Subclinical mastitis are most commonly addressed indirectly by SCC. Increase in milk SCC mainly corresponds to an afflux of white blood cells that come from the bloodstream into the milk to eliminate infection in the udder [13]. SCC is closely linked to the magnitude of the inflammatory process. Usually, only one quarter is infected and quarter-SCC is highly variable over infection time and according to both causative pathogen and host response. Therefore, single udder milk SCC are little informative and could be interpreted only if they are consistently low (uninfected cows) or repeatedly high (cows infected with major pathogens). Repeated measurements should be preferred for interpretation. Such repeated SCC data are routinely recorded for individuals on a monthly basis as part of milk recording schemes and stored in large data bases in many countries [51]. Distribution of SCC is highly skewed, with a majority of low values (lower than 100000 cells $/ \mathrm{mL}$ ) and a small proportion of very high values (up to several millions). On the other hand, most factors influence SCC in a multiplicative way. That is why SCC is usually transformed on a logarithm scale [2]. A usual definition is the somatic cell score: $\mathrm{SCS}=\log _{2}(\mathrm{SCC} / 100000)+3$.

Alternative indirect criteria related to the inflammatory parameters have been studied, such as lactose content, lactate dehydrogenase, NAGase [30]. The most promising one is milk electrical conductibility, provided that prediction of an infection is based on within individuals comparison across milking or across quarters [26]. Although specific milking devices have been developed, large-scale recording of conductivity has not yet been implemented and further work on the interpretation and modelling of data is still needed. Finally, recent works [18, 19, 37, 93] show that parameters of the immune response may be promising for studying genetics of mastitis resistance.

\subsection{Polygenic variability for mastitis resistance}

Differences between breeds are marked. These genetic differences could be estimated in herds with different breeds. Dairy breeds originating from eastern France (Montbéliarde, Abondance) or central Europe (Simmental, Brown Swiss) have lower SCC and clinical mastitis frequency than Holstein. Within breed, genetic variability is also quite large. The genetic standard deviation of clinical mastitis frequency reaches about 5\%. This means that in an environment with $20 \%$ average frequency of clinical mastitis, the frequencies observed for extreme genotypes range from $10 \%$ to $30 \%$. Similarly, the genetic standard deviation of SCC expressed in the $\log _{2}$ scale is 0.5 so that the ratio of genetically extreme SCC animals is around 4. Although this genetic variability is large, it is strongly diluted into the environmental variance, and the heritability, defined by the genetic variance/phenotypic variance ratio, is low for mastitis resistance traits.

Genetic parameters, such as heritability, phenotypic and genetic correlations, are statistical parameters to measure the genetic 
component of a trait or a group of traits. They do not require any knowledge about the number or the nature of the genes involved. They are estimated from phenotypic data by the correlation between relatives. These studies were essentially based on somatic cell counts and clinical mastitis records, but some scarce studies are also available for immunological parameters.

\subsubsection{Genetic parameters for bacteriological count, clinical mastitis, and SCC}

Heritability estimates of intramammary infection assessed by bacteriological analyses are scarce. Weller et al. [97] found a low values ranging from 0.02 to 0.04 . Detilleux et al. [19] and Wanner et al. [94], however, found higher values $(0.10$ to 0.20 ), based on 1237 and 756 cows, respectively.

Heritability estimates of clinical cases are more numerous and more accurate, being obtained from much larger data sets. Most estimates are between 0.02 and 0.04, according to the Scandinavian review of Heringstad et al. [27]. Similar values were reported in other countries $[59,68,97]$. To some extent, these consistently low values obtained on the observed binary scale, could be due to the too general definition of the trait, without any reference to the pathogens. They could also be explained by the binary nature of the trait. A frequently used alternative model assumes that a clinical case occurs when a non-observable normally distributed trait exceeds a threshold on an underlying scale. On this underlying scale, heritability estimates are higher, around 0.07 , with values up to $0.10[27,28$, 44]. Nevertheless, these values are still very low, making selection difficult to implement. This pattern, also observed for fertility or disease resistance traits, does not mean that there is no genetic variability, but, as already mentioned, that the genetic variability is diluted in a very large phenotypic variability.

Heritability estimates of SCS range from 0.05 to 0.14 for single monthly testday $[10,12,24,52,62,67]$. They tend to slightly increase from the beginning to the end of the lactation due to a constant genetic variance and a decreasing environmental variance. Furthermore, although the phenotypic correlation between test-day is rather low (about 0.3), the genetic correlation between adjacent test-day SCS is higher than 0.95 and decreases slightly to 0.7 between the beginning and the end of the lactation. The lactation measure of SCS (LSCS), obtained by averaging the individual test-day records, show a consistent higher heritability estimate around 0.15 with a range from 0.10 to $0.18[51,59,68]$. Genetic correlation of LSCS across lactations is rather high (higher than 0.8 in most breeds) so that genetic determinism of SCC is close within and across lactations.

Genetic correlation between SCS and bacterial infection was estimated to be near unity [97], indicating that SCS and subclinical infections are essentially the same trait. The corresponding correlation estimate with clinical mastitis, however, was positive but rather low, i.e. 0.30 [97]. Additional data, however, would be useful, especially to validate this result and to differentiate relationships with different kinds of pathogens. Most estimates of genetic correlation between SCC and clinical mastitis, originating from Scandinavian data, range from 0.50 to 0.80 , with an average of 0.70 [46, $56,68,72]$. This reasonably high value suggests that SCS and clinical cases are partly the expression of the same trait that involves common genes, despite a low phenotypic correlation (around 0.3). Indeed, using monthly SCC allows only the detection of $30 \%$ of clinical cases because of duration of $\mathrm{CM}$ and potentially different pathogens involved. 


\subsubsection{Genetic variability of immune mechanisms underlying mastitis resistance}

Some authors investigated the genetic determinism of innate and acquired immunity traits related to mastitis resistance in dairy cattle. Immunity traits studied were mainly antibody response and functionality of neutrophils, which recruitment and activity are essential in the innate defence against udder infection [78, 87]. Several authors [36, 43, 49] reported a significant sire effect of in vitro phagocytosis of blood neutrophils. Detilleux et al. [19] found moderate heritabilities for migration (0.2 to 0.5$)$ and phagocytosis $(0.3-0.7)$ of neutrophils and for serum complement activity (0.4-0.5), using in vitro assays for 137 cows sampled three times around calving. Using the same data, Kelm et al. [37] estimated correlations between breeding values for the different traits and showed that animals with low somatic cell counts, clinical mastitis frequency and intramammary infections tended to exhibit better functionality of neutrophils. These cows were additionally vaccinated with an inert antigen, ovalbumin, and with Escherichia coli [94]. Ranking of cows according to responses for both challenges was similar. Heritability estimates of serum antibody response were high, though variable, and ranged from 0.32 to 0.64 for ovalbumin and between 0.13 to 0.88 for E. coli. Genetic selection for increasing antibody responsiveness seems to be possible, but it should be pointed out that trends for association with clinical mastitis occurrence were not straightforward and that further investigations are needed to address genetics of immunology in mastitis.

\subsection{Major genes for mastitis resistance: candidate genes}

Resistance to mastitis is a complex function involving various biological pathways, molecules and cells. Therefore numerous functional candidate genes could be involved in the determinism of the function as reported by Detilleux [18]. In this paper, we will report only studies based on genetic analysis of association between mastitis resistance and candidate genes.

\subsubsection{Blad, lactoferrin and lysozyme}

Several authors focused on a mutation in the CD18 gene (BTA1) associated with bovine leukocyte adhesion deficiency (Blad) in Holstein cattle [35, 85]. The CD18 gene encodes the $\beta$-subunit of an integrin family of adhesion molecules, and the deleterious allele leads to no expression of $\beta 2$-integrin adhesion molecules on the surface of leucocytes. Cattle that are homozygous for the deleterious allele exhibit impaired diapedesis of leucocytes, extreme sensitivity in any infection and premature death. However, no difference in susceptibility to intramammary infections has been found in heterozygous carriers at the CD18 gene [37, 94]. Similarly, in their QTL experiment, Boichard et al. [9] did not observe any association between transmission of the deleterious Blad allele and SCC.

Seyfert et al. [80] focused on two genes encoding proteins present in milk and involved in the innate mechanisms of defence of the udder: on the one hand, lactoferrin (BTA22), an iron binding protein with bacteriostatic properties essentially in the involuted mammary gland, and, on the other hand, lysozyme (BTA5) which can specifically cleave bacterial cell walls. However, the preliminary trend of an implication of a lactoferrin variant in mastitis resistance found in their study population has not been confirmed by further publications.

\subsubsection{Major Histocompatility Complex}

Most extensively studied genes were those encoding the bovine major histocompatibility complex (MHC or BoLA) molecules (BTA23), because of their essential role in the induction and regulation of acquired immune response [66]. The MHC 
is organized in different clusters of genes, including class I, II and III genes. On the one hand, Class I molecules are expressed at the surface of all nucleated cells and interact with cytotoxic $\mathrm{T}$ lymphocytes $(\mathrm{CD} 8+)$. On the other hand, class II molecules, which expression is restricted to antigen presenting cells, are involved in antigen presentation to helper $\mathrm{T}$ lymphocytes cells (CD4+) and in the development and differentiation of T cells [66].

Some studies report association between Class I alleles and mastitis traits. Using gene substitution models (GSM), Weigel et al. [95] reported significant association between allele A14(A8) and decreased California Mastitis Test score, and between allele A11 and decreased clinical mastitis in 82 American Hosltein cows. Using logistic regression on 333 cows of various Danish breeds, Aarestrup et al. [1] reported a consistent association of alleles A11 and A12(A30) with decreased SCC, whereas alleles A21 and A26 were associated to increased cell counts. Additionally, the latter authors showed favourable effect of allele A19 and unfavourable effect of alleles A10(w50) and A31 on bacterial infections. Consistently with preliminary Norwegian results of Solbu et al. [86], Mejdell et al. [50] found decreased clinical mastitis for allele A2, based on GSM applied to breeding values of 424 Norwegian bulls. Authors also reported increased clinical mastitis for A7(w50) allele, but frequency of the latter allele in bulls was low $(1.2 \%)$. Mallard et al. [47] studied the effect of MHC alleles on antibody response to experimental intra mammary infection with Staphylococcus aureus in 124 cows. Using GSM, they found significantly higher antibody responses for alleles A3. In agreement with previously mentioned results of Aarestrup et al. [1] and Mejdell et al. [50], who found unfavorable relationships between A26 and cell counts and between A7(w50) and clinical mastitis, respectively, Mallard et al. [47] also reported that alleles A7(w50), and A26 were associated with significantly lower antibody response to
S. aureus. Such an association was also significant for allele w4(w50). Thus, many class I alleles were found to be associated with either susceptibility or resistance to mastitis. Based on at least two independent results alleles, one can conclude that A11 is associated with susceptibility whereas alleles A26 and A7(w50) are associated to resistance to mastitis.

As for Class I genes, several studies investigated relationships between BoLA Class II alleles and different mastitis indicators (see Tab. I). Nearly all of them focused on the exon 2 of the Class II DRB3 locus because of its high polymorphism (http://www.projects.roslin.ac.uk/bola/) and because it encodes the antigen adhesion site of CMH molecules [66]. Three authors showed significant association of allele DRB3. $2 * 24$ with susceptibility to mastitis (Tab. I): more intra mammary infections with major pathogens [37], more clinical mastitis [85, 90] and higher SCC [90]. Most results, however, were inconsistent across the five reported studies (Tab. I). For instance allele DRB3.2*16 was associated with either higher [20, 37] or lower [83, 89] cell count. Similar inconsistent trends were reported for DRB3.2*23 and DRB3.2*8 (Tab. I). Several explanations could be given to explain such trends. First, alleles may be related to resistance or susceptibility according to environmental conditions (present pathogens), which may be different in the five studied populations. More likely, the studied polymorphisms were not causal but linked to other MHC loci involved in mastitis resistance, which would lead to different associations according to families. Thus, analysis of effect of MHC haplotypes rather than single locus should be preferred.

Finally, it has been suggested that alleles associated with resistance to one disease could be associated with susceptibility to other diseases. Many studies are needed to estimate all the effects of MHC polymorphism, before it could be recommended to 
Table I. Significant associations between MHC ClassII DRB3 alleles and different indicators of mastitis.

\begin{tabular}{|c|c|c|c|c|}
\hline Reference & Data & Model $^{\mathrm{a}}$ & Allele & Effect $^{\mathrm{b}}$ \\
\hline Dietz et al. [20] & 584 cows & $\begin{array}{l}\text { Logistic regression } \\
\text { (case control) }\end{array}$ & DRB3.2*16 & - Higher acutely elevated SCC \\
\hline Kelm et al. [37] & 137 cows & GSM & $\begin{array}{l}\text { DRB3. } 2 * \mathbf{1 6} \\
\text { DRB3. } 2 * 8 \\
\text { DRB3. } 2 * 11 \\
\text { DRB3. } 2 * 23 \\
\text { DRB3. } 2 * 24 \\
\text { DRB3.2*3 }\end{array}$ & $\begin{array}{l}\text { - Higher SCC } \\
\text { - More CM } \\
\text { + Less CM } \\
\text { + Less CM } \\
\text { - More IMI with major pathogens } \\
\text { - More IMI with minor pathogens }\end{array}$ \\
\hline $\begin{array}{l}\text { Starkenburg et al. } \\
\text { [89] }\end{array}$ & 186 cows & GSM & $\begin{array}{l}\text { DRB3. } 2 * 3 \\
\text { DRB3. } 2 * \mathbf{1 6} \\
\text { DRB3. } 2 * \mathbf{7} \\
\text { DRB3. } 2 * \mathbf{2 2} \\
\text { DRB3. } 2 * \mathbf{2 4} \\
\text { DRB3.2*24 } \\
\text { DRB3.2*8 }\end{array}$ & $\begin{array}{l}\text { + Lower SCC } \\
\text { + Lower SCC } \\
\text { - Higher SCC } \\
\text { - Higher SCC } \\
\text { - Higher SCC } \\
\text { - More CM } \\
\text { + Less CM }\end{array}$ \\
\hline Sharif et al. [83] & $\begin{array}{l}835 \text { cows } \\
\text { (Hoslteins) }\end{array}$ & GSM & $\begin{array}{l}\text { DRB3. } 2 * \mathbf{1 6} \\
\text { DRB3. } 2 * \mathbf{2 3}\end{array}$ & $\begin{array}{l}\text { + Lower SCC } \\
\text { - More severe CM }\end{array}$ \\
\hline Sharif et al. [84] & $\begin{array}{l}835 \text { cows } \\
\text { (Holsteins) }\end{array}$ & $\begin{array}{l}\text { Fisher test } \\
\text { (case control) }\end{array}$ & $\begin{array}{l}\text { DRB 3. } 2 * \mathbf{8} \\
\text { DRB 3. } 2 * \mathbf{2 2} \\
\text { DRB3. } 2 * \mathbf{2 3} \\
\text { DRB } 3.2 * \mathbf{2 4}\end{array}$ & $\begin{array}{l}\text { - More CM with Staphilococci } \\
\text { - More CM with Staphilococci } \\
\text { - More CM with Staphilococci } \\
\text { - More CM with Staphilococci }\end{array}$ \\
\hline
\end{tabular}

${ }^{\mathrm{a}} \mathrm{GSM}=$ gene substitution effect model $;{ }^{\mathrm{b}} \mathrm{SCC}=$ somatic cell counts; $\mathrm{CM}=$ clinical mastitis IMI $=$ intra mammary infection: $+=$ resistance; $-=$ susceptibility.

implement any selection strategy on single alleles.

\subsection{Detection and localisation of Quantitative trait loci (QTL)}

QTLs are chromosomal regions responsible for a fraction of the genetic variability of a trait. They are detected by linked polymorphic markers that co-segregate with the QTL from parent to progeny. QTL detection does not require any prior knowledge about the genes but an appropriate family structure, with parents heterozygous for the QTL and for a linked marker, and many progeny with phenotypic and marker information. At least 150 markers are needed to span the entire genome and guar- antee a high detection power of a QTL located anywhere on the genome.

Several large QTL detection designs have been carried out in dairy cattle throughout the world. Mastitis resistance was studied using either SCC or, less frequently, clinical mastitis events as phenotypes. QTL were found on almost all chromosomes, and several were confirmed by at least two independent studies (Tab. II). Such "confirmed" QTL exist on chromosome 1, 3, 7, 8, 18, 21 and 23 for SCC, and on chromosome 14 for clinical mastitis (Tab. II). Few chromosomes (BTA3, 4, 11, 18 and 27) exhibited QTL for both SCC and clinical mastitis, but results came from distinct studies. Only Schulman et al. [79], analysed SCC and 
Table II. QTLs for mastitis resistance traits in literature.

\begin{tabular}{|c|c|c|c|c|}
\hline Chromosome & Trait & Study & Closest marker (position cM) & Significance $^{1}$ \\
\hline \multirow[t]{2}{*}{1} & SCS & Reinsch et al. [63] & MAF 46 & $*$ \\
\hline & SCS & Schulman et al. $[79]^{\mathrm{h}}$ & $?(59)$ & $* * *$ \\
\hline \multirow[t]{3}{*}{3} & SCS & Shrooten et al. $[76]^{f}$ & BMC5227 (171) & $*$ \\
\hline & SCS & Schulman et al. $[79]^{\mathrm{h}}$ & $?(109)$ & $* * *$ \\
\hline & $\mathrm{CM}$ & Klungland et al. [38] ${ }^{\mathrm{g}}$ & BR4502 & $*$ \\
\hline \multirow[t]{2}{*}{4} & SCS & Zhang et al. [99] ${ }^{\mathrm{c}}$ & RM188-TGLA116 (0-46) & $* * *$ \\
\hline & $\mathrm{CM}$ & Klungland et al. [38] ${ }^{\mathrm{g}}$ & BM6458-BMS1074 & $*$ \\
\hline 5 & SCS & Heyen et al. [29] ${ }^{\mathrm{d}}$ & BM315 & ** \\
\hline 6 & $\mathrm{CM}$ & Klungland et al. [38 ${ }^{\mathrm{g}}$ & FBN12 & $* * *$ \\
\hline \multirow[t]{2}{*}{7} & SCS & Heyen et al. [29] ${ }^{\mathrm{d}}$ & BMS1979 & $* *$ \\
\hline & SCS & Van Tassel et al. [91] $]^{\mathrm{e}}$ & BM6117 (61) & * \\
\hline \multirow[t]{2}{*}{8} & SCS & Reinsch et al. [63] & BM3419 & * \\
\hline & SCS & Klungland et al. [38] ${ }^{\mathrm{g}}$ & TGLA13, INRA122 & * \\
\hline 9 & SCS & Boichard et al. [9] ${ }^{\mathrm{j}}$ & BMS1967 (125) & $*$ \\
\hline 10 & SCS & Boichard et al. [9] j & DICK20 (86) & ** \\
\hline \multirow[t]{2}{*}{11} & SCS & Schulman et al. [79] ${ }^{\mathrm{h}}$ & $?(68)$ & $* * *$ \\
\hline & $\mathrm{CM}$ & Elo et al. [23] $]^{\mathrm{a}}$ & $?$ & * \\
\hline 13 & SCS & Zhang et al. $[99]^{\mathrm{c}}$ & TGLA381-AGLA232 (78-140) & \\
\hline \multirow[t]{3}{*}{14} & SCS & Zhang et al. [99] ${ }^{\mathrm{c}}$ & ILSTS11-BM302 (0-65) & $* * *$ \\
\hline & $\mathrm{CM}$ & Schulman et al. $[79]^{\mathrm{h}}$ & $?(25)$ & $* * *$ \\
\hline & $\mathrm{CM}$ & Klungland et al. [38 ${ }^{\mathrm{g}}$ & BM6425 & $*$ \\
\hline 15 & SCS & Boichard et al. [9] ${ }^{\mathrm{j}}$ & BMS2684 (88) & $* * *$ \\
\hline \multirow[t]{3}{*}{18} & SCS & Shrooten et al. $[76]^{f}$ & BM7109-ILSTS002 (70) & $*$ \\
\hline & SCS & Schulman et al. [79] & $?(111)$ & $* * *$ \\
\hline & $\mathrm{CM}$ & Schulman et al. [79] $]^{\mathrm{h}}$ & $?(111)$ & $* * *$ \\
\hline 19 & $\mathrm{CM}$ & Elo et al. [23] ${ }^{\mathrm{a}}$ & $?$ & $*$ \\
\hline \multirow[t]{3}{*}{21} & SCS & Heyen et al. [29] ${ }^{\mathrm{d}}$ & ETH131 & $* *$ \\
\hline & SCS & Schulman et al. $[79]^{\mathrm{h}}$ & $?(51)$ & $* * *$ \\
\hline & SCS & Boichard et al. [9] & TGLA122 (90) & $*$ \\
\hline 22 & SCS & Heyen et al. [29] ${ }^{d}$ & BM3628-CSSM26 & * \\
\hline \multirow[t]{3}{*}{23} & SCS & Reinsch et al. $[63]^{\mathrm{b}}$ & RM033 & $*$ \\
\hline & & Heyen et al. [29] ${ }^{d}$ & MGTG7 & $*$ \\
\hline & & Boichard et al. $[9]^{\mathrm{j}}$ & RM33 (19) & * \\
\hline 24 & SCS & Schulman et al. $[79]^{\mathrm{h}}$ & $?(28)$ & $* * *$ \\
\hline 26 & SCS & Zhang et al. [99] ${ }^{\mathrm{c}}$ & TGLA429-BM804 (71-82) & $* * *$ \\
\hline \multirow[t]{2}{*}{27} & SCS & Schulman et al. [79] ${ }^{\mathrm{h}}$ & $?(1)$ & $* * *$ \\
\hline & $\mathrm{CM}$ & Klungland et al. [38 ${ }^{\mathrm{g}}$ & BM1857, INRA27 & $*$ \\
\hline 29 & SCS & Schulman et al. $[79]^{\mathrm{h}}$ & $?(16)$ & $* * *$ \\
\hline
\end{tabular}

${ }^{a}$ Granddaughter design (GDD) of 12 Finnish Ayrshire families involving about 500 bulls; 84 markers; multiple marker regression analysis (MMR).

$\mathrm{b}$ GDD of 14 families involving 769 German Holstein bulls; 45 markers; single marker regression across families.

c GDD of 14 AI families with 1794 Holstein sons; 206 markers; MMR.

$\mathrm{d}$ GDD of 8 North American Holstein Frisian families with 1068 sons; 174 markers; MMR.

e GDD of 8 US Holstein families with about 800 sons; 105 markers; single marker regression with family.

${ }^{\mathrm{f}}$ GDD of 20 Dutch Holstein Frisian families involving 853 bulls; 277 markers; MMR.

g GDD of 6 Norwegian cattle families with 285 sons; 288 markers; MMR.

$\mathrm{h}$ GDD of 12 Finnish Ayrshire families and 461 sons; 148 markers; MMR.

$\mathrm{j}$ GDD of 14 families from Holstein, Normande and Montbeliarde breeds, and 1554 bulls; 168 markers; MMR. $1 * * *$ Experiment wise significance (experiment suggestive significance); ** chromosome wise significance $P<5 \%$; $*$ chromosome wise significance $P<1 \%$. 
clinical mastitis simultaneously and found co-segregation between traits on BTA18. Klungland et al. [38] did not observe such co-segregation. Thus, several chromosomal regions have large effects on mastitis resistance. The multitude of results reflects, to some extent, the fact that mastitis resistance is a complex function that involves many molecules and pathways that can be regulated by many different genes. Apart from few consensual findings, however, results seem to be specific to traits and population considered. Environmental conditions (exposure to pathogens) and genetic background of studied populations and breeds, may greatly influence the magnitude of links between genes and phenotypes. Similarly, clinical mastitis and SCC may reflect resistance to different type of pathogens and involve different resistance mechanisms.

\subsection{Genetic relationships with other traits}

\subsubsection{Relationships with udder type traits}

It is well established that a favourable association exists between mastitis resistance and several udder type traits. Generally, SCC and clinical mastitis show similar relationships with a given udder trait. Udder depth and udder attachment generally show consistent results indicating that higher and more tightly attached udders are associated with lower SCC and less clinical mastitis. Corresponding genetic correlations with both SCC and clinical mastitis range from -0.19 to $-0.70[5,40,45,65,68$, $82,88]$. Some authors also found significant association of mastitis traits with udder balance [68, 88]. Relationship with teat length is less clear.

\subsubsection{Relationships with milking ease}

Milking ease (or milking speed according to studies) is antagonistic to SCC: fast milking cows are found to have a large number of somatic cells in milk. From several recent studies based on large data sets $[5,45,46,68]$, the corresponding genetic correlation is close to 0.40 , and estimates ranged from 0.27 to 0.57 . In earlier studies, Seykora and McDaniel [81] showed similar trends with the percent of 2-min milk, defined as the percent of the total milk obtained in the first two min after attachment of teat cups. Larroque et al. [39] found a similar approximate estimation of genetic correlation (0.37) using Multiple trait Across Country Evaluation (MACE) methodology based on very large data sets and bull breeding values. The relationship of milking speed with clinical mastitis, however, is not consistent with results for SCC. Indeed, literature data essentially indicate favourable or almost null estimates of genetic correlation: -0.57 [40], -0.29 [45], -0.11 and -0.20 [46], and 0.06 [68]. Additionally, Sorensen et al. [89] reported estimates ranging from -0.34 to 0.17 , using six different definitions for clinical mastitis according to DIM, most values ranging from -0.11 to 0.07 . Inconsistency of results for relationships between milking ease, SCC and clinical mastitis do hardly support the argument that easier flow of milk out of the udder is associated with easier entry of pathogens or, therefore, increased risk of mastitis. As an alternative explanation, association of fast milking speed with increased SCC could result, to some extent, from a more complete draining of the udder as the last milking fraction has higher cell counts [68]. Additionally, fast milking cows could also be more prone to mild infection but, at the same time, be able to better avoid clinical expression due to more complete and rapid draining of the udder. Inconsistent and opposite genetic correlations may reflect different associations of milking characteristics of the cow and susceptibility to various pathogens. Further investigation on relationships is needed to clarify relationships between characteristics of milk emission and mastitis resistance. 


\subsubsection{Relationships with milk production traits}

The genetic antagonism between mastitis resistance and production traits has been well established. In their review, Mrode and Swanson [51] reported a weighted average genetic correlation between SCS and milk yield in first lactation of $0.14 \pm 0.04$. Most recent literature data $[45,58,68]$ gave similar results. Inverted pattern in later parities (favourable association) found in some studies may be due to culling strategies based on both production and health of animals. The genetic antagonism between yields and clinical mastitis is more pronounced. Based on Scandinavian data, Heringstad et al. [27] reported genetic correlations ranging from 0.24 to 0.55 with an average of 0.43 . From seven earlier studies involving lower numbers of animals, Emanuelson et al. [25] indicated an average value of 0.30. Estimates of Pryce et al. [59], Rupp and Boichard [68], and Kadarmideen et al. [33] were in the same range, i.e., $0.29,0.49$ and 0.35 , respectively. The interpretation of the antagonism between mastitis resistance and milk production is not straightforward. Pleiotropic genes could be involved, but also biological competition for energy and nutrients between functions [64].

\subsubsection{Relationships with fertility and functional longevity}

From few available studies lower mastitis resistance is genetically correlated to reduced fertility. Weller and Ezra [96] found a correlation of SCS and conception index (inversely correlated to the number of inseminations to conception) of -0.37 . Higher incidence of clinical mastitis [33, 58] and higher cell counts [58] were associated with (i) longer calving interval, (ii) higher number of days to first service (genetic correlation ranging from 0.16 to 0.41 ) and, (iii) lower conception rate to first service $(-0.21$ to -0.58$)$. Castillo-
Juarez et al. [11] also reported that high somatic cell counts were correlated to reduced conception rate at first service with genetic correlation of -0.21 and -0.14 . Similarly, the estimated genetic correlation between SCC and post partum conception rate was -0.12 [21]. Such relationships are probably indirect and could be explained by the antagonism observed between functional traits and production.

As expected, mastitis resistance is found to be an important component of cow's longevity. Sander Nielsen et al. [71] reported a high genetic association between udder disease (including mastitis as well as teat problems) and survival from first calving to end of second lactation. Corresponding genetic correlations ranged from -0.37 to -0.75 according to the breed. Genetic correlations of lifespan with somatic cell counts and clinical mastitis ranged from -0.11 to -0.32 according to Mrode et al. [53] and Pryce and Brotherstone [58]. Consistently, Jensen et al. [32] found a correlation of -0.40 between breeding values for functional longevity (lifespan corrected for production) and for clinical mastitis. Ducrocq et al. [21], similarly, reported a favourable estimated genetic correlation of 0.40 between SCS and functional longevity.

\section{APPLICATION: SELECTION FOR MASTITIS RESISTANCE}

The first step of selection implementation is the definition of the breeding objective, i.e. the combination of traits to improve to fulfil breeder's requirements and consumer's concern. Once this objective is chosen, criteria to select for should be defined such that they are strongly correlated to the objective and easy and cheap to measure on the candidates and/or their close relatives. The next step, called genetic evaluation, is the prediction of the breeding values of the candidates from the phenotypic and the pedigree information. Finally, 
the last step is the selection stricto sensu of the best candidates as parents of the next generation. The genetic progress from one generation to the next is then proportional to: (i) the genetic standard deviation, (ii) the selection differential, i.e. the superiority in estimated breeding value of the selected parents over the candidates, and (iii) the accuracy of the evaluation, i.e. the correlation between the true and the estimated breeding values.

\subsection{Definition of the breeding objective}

The breeding objective is usually a linear combination of traits of interest, weighed by their economic importance. Such an objective maximizes profitability. The genetic response on each trait, however, is not proportional to its weight but depends also on the accuracy of the genetic evaluation and the correlation among traits. That is why weights are often modified to account for additional constraints, for instance in order to avoid unfavourable trends for some traits. Up to the mid-90s, in most countries, the breeding objective included primarily production traits (mainly protein and fat yield), milk composition (protein and fat contents), and several morphological traits, particularly capacity and udder type. The Scandinavian countries were an exception with a more diverse breeding objective including many functional traits and, particularly, mastitis resistance [27]. In the last five years, the continuous and unfavourable trend for fertility and mastitis susceptibility led most European dairy populations to update their breeding objective and to increase the weight of non production trait. A review of the recently defined breeding objectives shows that mastitis resistance accounts for 10 to $30 \%$ of the total weight $[14,15,54]$. This weight is large enough to substantially decrease SCC and to stop any deterioration of CM frequency, even if SCC information only is available [15].

\subsection{Selection criteria: clinical mastitis or somatic cell counts?}

Direct selection against clinical mastitis is difficult, because in most countries clinical mastitis events are not widely recorded, and because its heritability is very low. Conversely, several arguments promote the interest of SCC in the selection for mastitis resistance. First, SCC is routinely recorded in most milk recording systems. Second, heritability of SCC is greater than for clinical mastitis. Finally, the genetic correlation between both traits is positive and moderate to high. Therefore, it is believed that selection for decreased SCC would reduce susceptibility to clinical and subclinical mastitis. Indirect response for clinical mastitis, however, will depend on the strength of the genetic correlation between SCC and clinical mastitis but also on the linearity of the relationship between both traits. Thus, whereas selection against cows with high SCC is supposed to reduce mastitis incidence, the question is now raised whether SCC should be decreased to the lowest possible value or should not be lower than a critical threshold.

Indeed, some authors $[34,78]$ were concerned by the recommendation of continuously decreasing SCC by selection, and argued that such a trend could impair the cow's capacity for leukocyte recruitment and, therefore, her ability to respond to intramammary infection. According to the latter authors, cows with very low SCC would be more susceptible to mastitis. These arguments arise out of studies reporting that moderate cell counts in milk play a protective role in the defense of the mammary gland [74, 75, 77]. These authors found that quarters with high or moderate initial SCC (400000-600000 and about 300000 cells $/ \mathrm{mL}$, respectively) had lower risk of being infected after experimental challenge with mastitis pathogens. Additionally, protective effect of mild infections with minor pathogens against more severe mastitis, principally caused by major pathogen, had been observed earlier $[57,60,74$, 
75]. Finally, authors who investigated SCC and mastitis at the herd level [22, 92], showed that lowest bulk milk SCC were significantly associated with higher clinical mastitis frequency.

Different conclusions were reported by authors who analyzed the relationship between individual SCC at a given time and natural occurrence of mastitis, defined by either high cell counts $[6,13]$ or clinical cases $[3,69,70]$ later in lactation. Results of all these studies were consistent, even when contrasted herd epidemiological situations were considered [69, 70]. No increase in susceptibility to intrammamary infection has been shown for very low SCC. On the contrary, results suggest that cows with the lowest observed SCC are always at the lowest risk of mastitis. Low levels of SCC, however, must not be considered as a causal effect on resistance, but an indirect predictor. Migration (from blood to mammary gland) and killing ability of cells, as well as type of cells present in milk may be the major key to resolve infections. Inconsistency of these findings with results based on experimental challenge for low SCC cows $[74,75,77]$ could result from different biological characteristics; in natural conditions, low SCC may reflect an efficient anatomical barrier which minimizes the risk of subsequent mastitis, whereas in experimental-infection conditions, this first anatomical line of defense of the cow is forced, and then the presence of SCC, minor pathogens, or both, in the mammary gland provides some protection against major pathogens. Difference may also result from the fact that, before challenge or in natural conditions, bacteriological status of the mammary gland, is not always known.

Additionally, several authors investigated the linearity of the relationship between SCC and clinical mastitis using results of genetic evaluation on large populations. McDaniel [48] found that one unit change in sire breeding value for SCC, corresponded to an increase of $36 \%$ in mastitis incidence. Philipsson et al. [55], and
Cranford and Pearson [16] reported similar linear association in Swedish, Danish, and US bulls. All these studies suggested that SCC could and should be decreased to the lowest possible value.

Accumulating results tend to show that, at least in the context of natural infections and on an individual basis, selection for decreased SCC should be effective to reduce clinical mastitis incidence and that the breeding goal should favor cows with the lowest observed SCC. This result is valid under the current situation and will need periodic confirmation on the long term, should the average SCC level substantially decrease in the population. Moreover, further investigation is needed to explain the discrepancy between studies based either on natural or experimental infections. A better understanding of defense mechanism that are involved and modified by a selection on phenotypic traits would be helpful. The best way to avoid undesirable consequences of selecting only on SCC would be to use clinical mastitis as an additional selection criterion for mastitis resistance, as already done in Denmark, Finland and Sweden [27]. Therefore, when not available, large recording of clinical events, culling or treatments should be encouraged.

\subsection{Genetic evaluation and inclusion in breeding programs}

The most common genetic evaluation uses only SCC information [31, 51]. It relies on a linear model including a contemporary group effect, other environmental effects and cow's breeding value. In the simplest models, the analysed SCC trait is LSCS, the lactation SCS defined by the mean (or a weighted mean) of the test-day SCS. This choice is justified by the common genetic determinism of SCS all along the lactation. Similarly, as the genetic correlation of LSCS between lactations is rather high, many evaluation systems consider mean SCS as a repeated trait over time [7, 31, 51]. Models for monthly repeated records of SCC were developed 
[61]. In contrast, in the most complex models, each test-day SCS is analysed with a model assuming that the genetic and nongenetic variances vary with days in milk and parity, as well as genetic and nongenetic correlations $[42,73]$. Such models accommodate that the heritability of SCS increases with days in milk, due to a rather constant genetic variance and a decreasing environmental variance. These test-day models theoretically extract more information from the data, allow for a more accurate modelling of the data, and are less sensitive to non-regular SCC recording systems. They involve, however, a huge amount of records and are rather sensitive to the large number of parameters to infer. These complex approaches are more and more popular and tend to become the international reference.

When clinical mastitis events are routinely recorded, they are used as an additional source of information, to compute breeding values for mastitis resistance [27]. The criterion is usually defined in a binary way, combining clinical cases, treatments and culling [27]. This trait is modelled with a linear model or with a threshold model, theoretically better suited to the all-or-none nature of the trait. Because of the very low heritability of the trait, one phenotypic record is very little informative to estimate the breeding value of a cow. Even after accounting the information from the relatives, the estimated breeding value of a cow remains very inaccurate. High accuracy could be obtained only for bulls with large progeny groups. In practice, such an evaluation has been implemented in Sweden, Finland, Denmark, and Norway [27].

A strategic choice is the definition of mastitis resistance in the breeding objective, as one could be interested in resistance to clinical mastitis, to subclinical mastitis, or to both with any weighing. When the trait of interest is subclinical mastitis, the SCC phenotypic data provide enough information for bulls as well as for cows and there is little to gain by adding clinical mastitis or conformation information. In contrast, when the trait of interest is clinical mastitis, the accuracy of the evaluation is always limited, even when clinical events are widely recorded. Consequently, there is much to gain by adding indirect information, i.e. correlated traits with higher heritability. These predictors could include SCC and some udder conformation traits, particularly udder depth. To illustrate that point, it could be noticed that an indirect selection on SCC would give a better response on clinical mastitis than a direct selection on clinical mastitis. Some udder health indices have been proposed in some countries $[4,5,17]$, combining different predictors such as udder depth and milking ease. In practice, rigorously combining the information from different criteria is not straightforward. Ducrocq et al. [21] proposed a unified feasible procedure very similar to the optimal multiple trait approach. Additionally, including mastitis resistance in the breeding goal will slow down the genetic progress on production (milk yield and composition) because of antagonistic genetic correlation between these traits $[14,90]$.

In the last decade, information on QTL involved in the genetic determinism of SCC is accumulating. Although the underlying genes involved are still unknown, incorporation of this information in the classical genetic evaluation for markerassisted selection is under way. Although this new approach has not yet proven to be more efficient, it is already implemented in some countries and is believed to be very promising [8].

\section{CONCLUSION}

Genetics of mastitis resistance in dairy cattle has been studied for a long period. Most studies focused on milk SCC or clinical mastitis records as the phenotypic measure to account for mastitis resistance. SCC and clinical mastitis have an large genetic component, they are genetically 
correlated, and easily available at large scale. Moreover, mastitis resistance is genetically antagonistic to production traits, and there is increasing economic justification to include the trait in the breeding objective of the breeds. Therefore many countries have included SCC, clinical mastitis, or both, in their breeding programs in the last decades, as a way to improve resistance to intrammamary infections.

On the one hand, ongoing research aims to increase accuracy of such a selection by better modeling for SCC and clinical mastitis, combining these traits together and with predictor traits such as udder type. Additionally, work is developing to integrated recent QTL detection information in marker-assisted selection. On the other hand, much is still to be known about biological interpretation and relevance of phenotypic traits related to mastitis resistance. How to interpret antagonism between resistance to mastitis and production? Which components of resistance are involved when selecting on SCC and clinical mastitis: morphology of the udder, innate or immune mechanisms? How would long term selection act on these components? What consequences will selection have on the equilibrium between subclinical and clinical cases and among present pathogens? Non-classical phenotypes, such as bacteriology, immunology, other indirect measures, could help to address different facets of the trait. As a further approach to classical genetic analyses, epidemiological modeling, QTL detection and candidate gene approach $(\mathrm{CMH})$, and developing functional genomics may be useful tools in understanding the genetic determinism of mastitis resistance.

\section{REFERENCES}

[1] Aarestrup F.M., Jensen N.E., Ostergard H., Analysis of associations between major histocompatibility complex (BoLA) class I haplotypes and subclinical mastitis of dairy cows, J. Dairy Sci. 8 (1995) 1684-1692.
[2] Ali A.K.A., Shook G.E., An optimum transformation for somatic cell concentration in milk, J. Dairy Sci. 63 (1980) 487-490.

[3] Beaudeau F., Seegers H., Fourichon C., Hortet P., Association between milk somatic cell counts up to 400000 cells $/ \mathrm{mL}$ and clinical mastitis occurrence in French Holstein cows, Vet. Rec. 143 (1998) 685-687.

[4] Boettcher P.J., Van Doormaal B.J., Tools for selection for functional traits in Canada, Interbull, Bulletin 23 (1999) 29-39.

[5] Boettcher P.J., Dekkers J.C.M., Kolstad B.W., Development of an udder health index for sire selection based on somatic cell score, udder conformation, and milking speed, J. Dairy Sci. 81 (1998) 1157-1168.

[6] Boettcher P., Samoré A., Pagnacco G., Relationships between normal levels of somatic cells and the duration of mastitis infections. Proc. 7th World Congr. Genet. Appl. Livest. Prod, 2002, Paper 05-23.

[7] Boichard D., Rupp R., Genetic analysis and genetic evaluation for somatic cell score in French dairy cattle, Interbull, Bulletin 15 (1997) 54-60.

[8] Boichard D., Fritz S., Rossignol M.N., Boscher M.Y., Malafrosse A., Colleau J.J., Implementation of marker assisted selection in French dairy cattle, Proc. 7th World Cong. Genet. Appl. Livest. Prod., August 19-23, Montpellier, France, 2002, Paper 22-03.

[9] Boichard D., Grohs C., Bourgeois F., Cerqueira F., Faugeras R., Neau A., Rupp R., Amigues Y., Boscher M.Y., Leveziel H. Detection of genes influencing economic traits in three French dairy cattle breeds, Genet. Sel. Evol. 35 (2003) 1-25.

[10] Carnier P., Bettella R., Cassandro M., Gallo L., Mantovani R., Bittante G., Genetic parameters for test-day somatic cell count in Italian Holstein Frisian cows. Proc. 48th Ann. Meet. Eur. Assoc. Anim., 1997, p. 141.

[11] Castillo-Juarez H., Oltenacu P.A., Blake R.W., Mcculloch C.E., Cienfuegos-Rivas E.G., Effect of herd environment on the genetic and phenotypic relationships among milk yield, conception rate, and somatic cell score in Holstein cattle, J. Dairy Sci. 83 (2000) 807-814.

[12] Charfeddine N., Alenda R., Carabano M.J., Genetic parameters for somatic cell score within first lactation, and across lactations in Spanish Holstein-Frisian cattle, Proc. 48th Ann. Meet. Eur. Assoc. Anim. Prod., August 25-28, Vienna, Austria, 1997, p. 69. 
[13] Coffey E.M., Vinson W.E., Pearson R.E., Somatic cell counts and infection rates for cows of varying somatic cell count in initial test of first lactation, J. Dairy Sci. 69 (1986) 552-555.

[14] Colleau J.J., Le Bilan-Duval E., A simulation study of selection methods to improve mastitis resistance of dairy cows, J. Dairy Sci. 78 (1995) 659-671.

[15] Colleau J.J., Regaldo D., Définition de l'objectif de sélection dans les races bovines laitières,

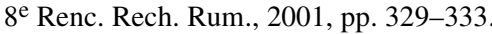

[16] Cranford J.L., Pearson R.E., Relationships of sire predicted transmitting ability for somatic cell score with measure of daughter performance, J. Dairy Sci. 84 (2001) 1501-1507.

[17] De Jong G., Lansbergen L., Udder health index: selection for mastitis resistnace, Interbull, Bulletin 12 (1996) 42-47.

[18] Detilleux J.C., Genetic factors affecting susceptibility of dairy cows to udder pathogens, Vet. Immunol. Immunopathol. 88 (2002) 103-110.

[19] Detilleux J.C., Koehler K.J., Freeman A.E., Kehrli M.E., Jr. Kelley D.H., Immunological parameters of periparturient Holstein cattle: genetic variation, J. Dairy Sci. 77 (1994) 2640-2650.

[20] Dietz A.B., Cohen N.D., Timms L., Kehrli E. Jr., Bovine Lymphocytre Antigen Class II alleles as risk factors for high somatic cell counts in milk of lactating dairy cows, J. Dairy Sci. 80 (1997) 406-412.

[21] Ducrocq V., Boichard D., Barbat A., Larroque H., Implementation of an approximate multitrait BLUP evaluation to combine production traits and functional traits into a total merit index, Proc. 52nd Ann. Meet. Eur. Assoc. Anim. Prod, August 26-29, Budapest, Hungary, 2001, p. 2.

[22] Elbers A.R.W., Milrenburg, J.D., Delange D., Crauwells A.P.P., Barkema H.W., Schukken Y.H., Risk factors for clinical mastitis in a random sample of dairy herds from the southern Part of the Netherlands, J. Dairy Sci. 81 (1998) 420-426.

[23] Elo K., Vilkki J., Koning de D.J., Velmala R., Honkatukia M., Moisio S., Karkkainen H., Maki-Tanila A., Mapping quantitativ trait loci for production, health and fertility traits in Finnish Ayrshire dairy cattle, Proc. 49th Ann. Meet. Eur. Assoc. Anim. Prod, August 24-27, Warsaw, Pland, 1998, p. 19.

[24] Emanuelson U., Philipsson J., Studies on somatic cell counts in milk from Swedish dairy cows. II. Estimates of genetic parame- ters for monthly test day results, Acta. Agric Scand. 34 (1984) 45-53.

[25] Emanuelson U., Danell B., Philipsson J., Genetic parameters for clinical mastitis, somatic cell counts, and milk production by multiple-trait restricted maximum likelihood, J. Dairy Sci. 71 (1988) 467-476.

[26] Hamann J., Zecconi A., Evaluation of the electrical conductivity of milk as a mastitis indicator, International Dairy Federation, Bulletin 334 (1998) 5-22.

[27] Heringstad B., Klemetsdal G., Ruane J., Selection for mastitis in dairy cattle: a review with focus on the situation of the Nordic countries, Livest. Prod. Sci. 64 (2000) 95-106.

[28] Heringstad B., Rekaya R., Gianola D., Klemetsdal G., Weigel K.A., Bayesian analysis of liability of clinical mastitis in Norwegian Cattle with a threshold model: effects of data sampling method and model specification, J. Dairy Sci. 84 (2001) 2337-2346.

[29] Heyen D.W., Weller J.I., Ron M., Band M., Beever J.E., Feldmesser E., Da Y., Wiggans G.R., VanRadden P.M., Lewin H.A., A genome scan for QTL influencing milk production and health traits in dairy cattle, Physiol. Genomics 1 (1999) 165-175.

[30] Holdaway R.J., Holmes C.W., Steffert I.J., A comparison of indirect methods for diagnosis of subclinical intramammary infections in lactating dairy cows. 2 . The discriminative ability of eight parameters in foremilk from individual quarters of cows, Austr. J. Dairy Tech. 51 (1996) 72-78.

[31] Interbull, Sire evaluation procedures for nondairy-production, and growth and beef production traits practiced in various countries, Bulletin 13 (1996).

[32] Jensen J., Korsgaard I.R., Neerhof H.J., Vollema A., Madsen P., Ducrocq V., Genetic variation in functional longevity and its relation to mastitis resistance in Danish Holstein, Interbull, Bulletin 21 (1999) 161-165.

[33] Kadarmideen H.N., Thompson R., Simm G., Linear and threshold genetic parameters for disease fertility and milk production in dairy cattle, Anim. Sci. 71 (2000) 411-419.

[34] Kehrli M.E. Jr., Shuster D.E., Factors affecting milk somatic cells and their role in health of the bovine mammary gland, J. Dairy Sci. 77 (1994) 619-627.

[35] Kehrli M.E. Jr., Schmalstieg F.C., Anderson D.C., van der Maaten J., Hughes B.J., Ackermann M.R., Wilhelmsen C.L., Brown G.B., Stevens M.G., Whetstone C.A., Molecular definition of the bovine granulocytopathy syndrome: identification of deficiency of 
the Mac-1 (CD11b/CD18) glycoprotein, Am. J. Vet. Res. 51 (1990) 1826-1836.

[36] Kehrli M.E. Jr., Weigel K.A., Freeman A.E., Thurston J.R., Kelley D.H., Bovine sire effects on daughters' in vitro blood neutrophil functions, lymphocyte blastogenesis, serum complement and conglutinin levels, Vet. Immunol. Immunopathol. 27 (1991) 303-319.

[37] Kelm S.C., Detilleux J.C., Freeman A.E., Kehrli M.E. Jr., Dietz A.B., Fox L.K., Butler J.E., Kasckovics I., Kelley D.H., Genetic association between parameters of innate immunity and measures of mastitis in periparturient Holstein cattle, J. Dairy Sci. 80 (1997) 1767-1775.

[38] Klungland H., Sabry A., Heringstad B., Olsen H.G., Gomez-Raya L., Vage D.I., Olsaker I., Odegard J., Klemetsdal G., Schulman N., Vilkki J., Ruane J., Aasland M., Ronningen K., Lien S., Quantitative trait loci affecting clinical mastitis and somatic cell count in dairy cattle, Mamm. Genome 12 (2001) 837-842.

[39] Larroque H., Rupp R., Moureaux S., Boichard D., Ducrocq V., Genetic parameters for type and functional traits in the French Holstein breed, Interbull, Bulletin 23 (1999) 169-179.

[40] Lawstuen, D.A., Hansen L.B., Steuernagel G.R., Johnson L.P., Management traits scored linearly by dairy producers, J. Dairy Sci. 71 (1988) 788-799.

[41] Lescourret F., Coulon J.B., Modeling the impact of mastitis on milk production by dairy cows, J. Dairy Sci. 77 (1994) 22892301.

[42] Liu Z., Reinhard F., Reents R., Parameter estimates of a random regression test-day model for first three lactation somatic cell scores, Interbull, Bulletin 27 (2000) 61-65.

[43] Lostrie Trussard N., Sartenaer D., Maquet G., Letersson J.J., Depelchin A., Les cellules phagocytaires du lait de vache : identification par des anticorps monoclonaux et étude fonctionnelle in vitro, Ann. Rech. Vet. 131 (1984) 49-62.

[44] Lund M.S., Jensen J., Petersen P.H., Estimation of genetic and phenotypic parameters for clinical mastitis, somatic cell production deviance, and protein yield in dairy cattle using Gibbs sampling, J. Dairy Sci. 82 (1999) 1045-1051.

[45] Lund T., Miglior F., Dekkers J.C.M., Burnside E.B., Genetic relationships between clinical mastitis, somatic cell count, and udder conformation in Danish Holsteins, Livest. Prod. Sci. 39 (1994) 243-255.

[46] Luttinen A., Juga J., Genetic relationship between milk yield, somatic cell count, mastitis, milkability and leakage in Finnish dairy cattle, Interbull, Bulletin 15 (1997) 78-83.

[47] Mallard B.A., Leslie K.E., Dekkers J.C.M., Hedge R., Bauman M., Stear M.J., Differences in bovine lymphocyte antigen associations between immune responsiveness and risk of disease following intramammary infection with Staphylococcus aureus, J. Dairy Sci. 78 (1995) 1937-1944.

[48] McDaniel B.T., Regression of incidence of clinical mastitis on sire evaluations for somatic cell score, J. Dairy Sci. 76 (1993) 238.

[49] McDonald E.A., Xia L., Monardes H., Turner J.D., Neutrophil function in vitro: diapedesis and phagocytosis, J. Dairy Sci. 77 (1994) 628-638.

[50] Mejdell C.M., Lie O., Solbu H., Arnet E.F. Spooner R.L., Association of major histocompatibility complex antigens (BoLA-A) with AI bull progeny test results for mastitis, ketosis and fertility in Norwegian cattle, Anim. Genet. 25 (1994) 99-104.

[51] Mrode R.A., Swanson G.J.T., Genetic and statistical properties of somatic cell count and its suitability as an indirect means of reducing the incidence of mastitis in dairy cattle, Anim. Breed. Abstr. 64 (1996) 847-857.

[52] Mrode R.A., Swanson G.J.T., Winters M.S., Genetic parameters and evaluations for somatic cell counts and its relationship with production and type traits in some dairy breeds in the United Kingdoms, Anim. Sci. 66 (1998) 569-576.

[53] Mrode R.A., Swanson G.J.T., Lindberg C.M., Genetic correlations of somatic cell count and conformation traits with herd life in dairy breeds, with an application to national genetic evaluations for herd life in the United Kingdom, Livest. Prod. Sci. 65 (2000) 119-130.

[54] Pedersen J., Sander Nielsen U., Aamand G.P., Economic values in the Danish Total Merit Index, Interbull, Bulletin 29 (2002) 150-154.

[55] Philipsson J., Ral G., Berglund B., Somatic cell count as a selection criterion for matitis resistance in dairy cattle, Livest. Prod. Sci. 41 (1995) 195-200.

[56] Pösö J., Mäntysaari A.E., Relationship between clinical mastitis, somatic cell score, and production for first three lactations of Finnish Ayrshire, J. Dairy Sci. 79 (1996) 1284-1291. 
[57] Poutrel B., Lerondelle C., Protective effect in the lactating bovine mammary gland induced by coagulase-negative staphylococci against experimental Staphylococcus aureus infections, Ann. Rech. Vét. 11 (1980) 327-332.

[58] Pryce J.E., Brotherstone S., Estimation of lifespan breeding values in the UK and their relationship with health and fertility traits, Interbull, Bulletin 21 (1999) 166-169.

[59] Pryce J.E., Esslemont R.J., Thompson R., Veerkamp R.F., Kossaibati M.A., Simm G., Estimation of genetic parameters using health, fertility and production data from a management recording system for dairy cattle, Anim. Sci. 66 (1998) 577-584.

[60] Rainard P., Poutrel B., Effect of naturally occurring intramammary infections by minor pathogens on new infections by major pathogens in cattle, Am. J. Vet. Res. 4 (1988) 327329.

[61] Reents R., Dekkers J.C.M., Schaeffer L.R., Genetic evaluation for somatic cell score with a test-day model for multiple lactations, J. Dairy Sci. 78 (1995) 2858-2870.

[62] Reents R., Jamrozik J., Schaeffer L.R., Dekkers, J.C.M., Estimation of genetic parameters for test day records of somatic cell score, J. Dairy Sci. 78 (1995) 2847-2857.

[63] Reinsch N., Xu N., Thomsen H., Looft C., Kalm E., Grupe S., Kuhn C., Schwerin M., Leyhe B., Hiendleder S., Erhart G., Medjugorac I., Russ I., Forster M., Brenig B., Reents R., Averdunk G., First results on somatic cell count loci from the ADR bovine mapping project. Proc. 6th World Congr. Genet. Appl. Livest. Prod. 26 (1998) 426-428.

[64] Rogers G., Aspects of milk composition, productive life and type traits in relation to mastitis and other diseases in dairy cattle, Proc. 7th World Congr. Genet. Appl. Livest. Prod., August 19-23, Montpellier, France, 2002, Paper 09-18.

[65] Rogers G.W., Hargrove G.L., Lawlor T.J., Ebersole J.L., Correlations among linear type traits and somatic cell counts, J. Dairy Sci. 74 (1991) 1087-1091

[66] Rothschild M.F., Skow L., Lamont S.J., The major Histocompatibility Complex and it's role in disease resistance and immune responsiveness, in: Axford R.F.E., Bishop S.C., Nicholas F.W., Owen J.B (Eds.), Breeding for disease resistance in farm animals, $\mathrm{CAB}$ International, 2000, pp. 73-105.

[67] Rupp R., Analyse génétique de la résistance aux mammites chez les ruminants laitiers, Ph.D. thesis, INA-PG/INRA, 2000.
[68] Rupp R., Boichard D., Genetic parameters for Clinical Mastitis, Somatic Cell Score, Production, Udder Type Traits, and Milking Ease in First Lactation Holsteins, J. Dairy Sci. 82 (1999) 2198-2204.

[69] Rupp R., Boichard D., Relationship of Early First Lactation Somatic Cell Count with Risk of Subsequent Clinical Mastitis, Livest. Prod. Sci. 62 (2000) 169-180.

[70] Rupp R., Beaudeau F., Boichard D., Association between somatic cell count in first lactation and occurrence of clinical mastitis in second lactation, Prev. Vet. Med. 46 (2000) 99-111.

[71] Sander Nielsen U., Pedersen G.A., Pedersen J., Jensen J., Genetic variation in disease traits and their relationships with survival in Danish dairy cattle, Interbull, Bulletin 21 (1999) 170-177.

[72] Sander Nielsen U., Pedersen G.A., Pedersen J., Jensen J., Genetic correlations among health traits in different lactations, Interbull, Bulletin 15 (1997) 68-77.

[73] Schaeffer L.R., Jamrozik J., Kistemaker G.J., Van Doormaal B.J., Experience with a TestDay Model. J. Dairy Sci. 83 (2000) 11351144.

[74] Schalm O.W., Caroll E.J., Lasmanis J., The leukocyte barrier and serologique investigations of experimental coliforms, Am. J. Vet. Res. 25 (1964) 90-96.

[75] Schalm O.W., Lasmanis J., Caroll E.J., Effect of preexisting leukocytosis on experimental coliform mastitis in cattle, Am. J. Vet. Res. 25 (1964) 83-89.

[76] Schrooten C., Bovenhuis H., Coppieters W., van Arendonk J.A.M., Whole genome scan to detect quantitative trait loci for conformation and functional traits in dairy cattle, J. Dairy Sci. 83 (2000) 795-806.

[77] Schukken V.H., Mallard B.A., Dekkers J.C.M., Leslie K.E., Stear M.J., Genetic impact on the risk of intramammary infection following Staphylococcus aureus challenge, J. Dairy Sci. 77 (1994) 639-647.

[78] Schukken Y.H., Lam T.J.G.M., Barkema H.W., Biological basis for selection on udder health traits, Interbull, Bulletin 15 (1997) 27-33.

[79] Schulman N.F., Moisio S.M., Koning de D.J., Elo K., Maki-Tanila A., Vilkki J., QTL for health traits in Finnish Ayrshire cattle. Proc. 7th World Congr. Genet. Appl. Livest. Prod., August 19-23, Montpellier, France, 2002, Paper 09-19. 
[80] Seyfert H.M., Henke M., Interthal H., Klussmann U., Koczan D., Natour S., Pusch B., Senft B., Steinhoff U.M., Tuckoricz A., Hobon G., Defining candidate genes for mastitis resistance in cattle: the role of lactoferrin and lysozyme, J. Anim. Breed. Genet. 113 (1996) 269-276.

[81] Seykora A.J., McDaniel B.T., Heritabilities of teat traits and their relationships with milk yield, somatic cell count, and percent twominute milk, J. Dairy Sci. 68 (1985) 26702683.

[82] Seykora A.J., McDaniel B.T., Genetics statistics and relationships of teat and udder traits, somatic cell counts, and milk production, J. Dairy Sci. 69 (1986) 2395-2407.

[83] Sharif S., Mallard B.A., Wilkie B.N, Sargeant J.M., Scott H.M., Dekkers J.C.M, Leslie E., Histocompatibility complex DRB3 alleles with occurrence of disease and milk somatic cell score in Canadian dairy cattle, Int. Soc. Anim. Genetics 29 (1998) 185-193.

[84] Sharif S., Mallard B.A., Sargeant J.M., Presence of glutamine at position 74 of pocket 4 in the BoLA-DR antigen binding groove is associated with occurrence of clinical mastitis caused by Staphylococcus species, Vet Immunol. Immunopathol. 76 (2000) 231238.

[85] Shuster D.E., Kehrli M.E. Jr., Ackermann M.R., Gilbert R.O., Identification and prevalence of a genetic defect that causes leukocyte adhesion deficiency in Holstein cattle, Proc. Natl. Acad. Sci. USA 89 (1992) 92259229.

[86] Solbu H., Spooner R.L., Lie O., A possible influence of the bovine major histocompatibility complex (Bola) on mastitis, Proc. 2nd World Congr. Genet. Appl. Livest. Prod., October 4-8, Madrid, Spain, 8 (1982) 368371.

[87] Sordillo L.M., Shafer-Weaver K., DeRos D., Immunobiology of the mammary gland, J. Dairy Sci. 80 (1997) 1851-1865.

[88] Sorensen M.K., Jensen J., Christensen L.G., Udder conformation and mastitis resistance in Danish first-lactation cows: heritabilities, genetic and environmental correlations, Acta Agric. Scand. 50 (2000) 72-82.

[89] Starkenburg R.J., Hansen L.B., Kehrli M.E. Jr., Chester-Jones H., Frequencies and effects of alternative DRB3.2 alleles of Bovine Lymphocyte Antigen for Holsteins milk selection and control lines, J. Dairy Sci. 80 (1997) 3411-3419.

[90] Strandberg E., Shook G.E., Genetic and economic responses to breeding programs that consider mastitis, J. Dairy Sci. 72 (1989) 2136-2142.

[91] Van Tassel C.P., Ashwell M.S., Sonstegard T.S., Detection of putative loci affecting milk yield, health, and conformation traits in the US Holstein Population using 105 Microsatellite markers, J. Dairy Sci. 83 (2000) 18651872.

[92] Waage S., Sviland S., Odegaard S.A., Identification of risk factors for clinical mastitis in dairy heifers, J. Dairy Sci. 81 (1998) 12751284.

[93] Wagter L.C., Mallard B.A., Wilkie B.N., Leslie K.E., Boettcher P.J., Dekkers J.C.M., A quantitative approach to classifying Holstein cows based on Antiobody responsiveness and its relationship to peripartum mastitis occurrence, J. Dairy Sci. 83 (2000) 488-498.

[94] Wanner J.M., Rogers G.W., Kehrli M.E., Cooper J.B., Intramammary infections in primiparous Holsteins: heritabilities and comparison of Bovine Leukocyte Adhesion deficiency carriers and noncarriers, J. Dairy Sci. 91 (1998) 3293-3299.

[95] Weigel K.A., Freeman A.E., Kehrli M.E. Jr., Stear M.J., Kelley D.H., Association of class I Bovine Lymphocyte Antigen complex alleles with health and production traits in dairy cattle, J. Dairy Sci. 73 (1990) 2538-2546.

[96] Weller J.I., Ezra E., Genetic analysis of somatic cell score and female fertility of Israeli Holsteins with an individual animal model, J. Dairy Sci. 80 (1997) 586-593.

[97] Weller J.I., Saran A., Zeliger Y., Genetic and environmental relationships among somatic cell count, bacterial infection, and clinical mastitis, J. Dairy Sci. 75 (1992) 2532-2540.

[98] Yancey R.J. Jr., Vaccines and diagnostic methods for bovine mastitis: fact and fiction, Adv. Vet. Med. 41 (1999) 257-273.

[99] Zhang Q., Boichard D., Hoeschele I., Ernst C., Eggen A., Murkve B., Pfister-Genskow M., Witte L., Grignola F.E., Uimari P., Thaller G., Bishop M.D., Mapping quantitative trait loci for milk production and health of dairy cattle in a large outbred pedigree, Genetics 149 (1998) 1959-1973. 